\title{
STRATEGI PENGEMBANGAN LEMBAGA PENDIDIKAN TAMAN KANAK-KANAK
}

\author{
Akbar Pandu Dwinugraha \\ Program Studi Administrasi Publik \\ Fakultas Ilmu Sosial dan Ilmu Politik Universitas Merdeka Malang \\ Korespondensi:akbar.dwi@unmer.ac.id
}

Article Histori:

Accepted: 28/3/2021

Review: 30/3/2021

Publish: 30/4/2021

\begin{abstract}
This study tries to provide a development strategy for kindergarten educational institutions. This strategy can later be used by local governments in developing kindergarten educational institutions in their respective regions. This study uses a combination research type with a survey method and will analyze three aspects including the management and implementation of kindergartens; aspects of the quality of educators and teaching staff; and aspects of the availability of basic equipment, facilities and infrastructure. The research location is the administrative area of Blitar City, East Java Province with data collection time from March to June 2019. Field data were collected using questionnaires, interviews, documentation and focus group discussions. Based on existing conditions, which have been analyzed based on internal and external factors, three strategic recommendations have been produced which include (1) Assistance in budgeting and monitoring the use of BOP funds (Operational Assistance for Early Childhood Education); (2) Increasing the cooperative relationship of kindergarten institutions through sponsorship schemes, (3) Standardization of minimal facilities and infrastructure as an effort to reduce the imbalance in the availability of facilities and infrastructure in kindergarten institutions in Blitar City.
\end{abstract}

Keyword: strategy, kindergarten, development, education

\section{PENDAHULUAN}

Taman Kanak-kanak atau biasa disingkat dengan TK merupakan salah satu lembaga pendidikan anak usia dini yang memiliki peranan sangat penting untuk mengembangkan kepribadian anak serta mempersiapkan mereka memasuki jenjang pendidikan selanjutnya (Masitoh: 2005). Berbeda dengan pendapat Masitoh dkk., Moeslichatoen (2004) menjelaskan bahwa tujuan Pendidikan TK adalah untuk membantu anak dalam meletakkan dasar ke arah perkembangan sikap, pengetahuan, keterampilan, dan daya cipta yang diperlukan oleh anak dalam menyesuaikan diri dengan lingkungannya dan untuk pertumbuhan serta perkembangan selanjutnya. Ketika merujuk pada UndangUndang Republik Indonesia Nomor 20 Tahun 2003 tentang Sisdiknas, Pasal 28 (3) 
dinyatakan bahwa pendidikan usia dini pada jalur pendidikan formal berbentuk Taman Kanak-Kanak (TK), sangat berbeda dengan lembaga pendikan SD, SMP, dan seterusnya. Dari nama lembaganya, yakni "taman" bukan "sekolah". Sebutan "Taman" pada Taman Kanak-kanak mengandung makna "tempat yang aman dan nyaman (safe and comfortable) untuk bermain" sehingga pelaksanaan pendidikan di TK harus mampu menciptakan lingkungan bermain yang aman dan nyaman sebagai wahana tumbuh kembang anak.

Peserta didik yang dapat ditampung dan belajar di TK adalah usia $4-6$ tahun dengan lama Pendidikan antara satu sampai dua tahun. Pelaksanaan pendidikan TK dikelompokkan menjadi dua yaitu kelompok TK A bagi anak usia 4 - 5 tahun dan kelompok TK B untuk anak usia 5 - 6 tahun. Pengelompokan ini bukan merupakan jenjang yang harus diikuti oleh setiap anak didik. Dengan kata lain, bahwa setiap anak didik dapat berada selama satu tahun pada Kelompok A atau Kelompok B, atau selama dua tahun pada Kelompok A dan Kelompok B.

Tujuan diadakan pendidikan TK adalah (a) membantu pertumbuhan dan perkembangan jasmani dan rohani agar anak memiliki kesiapan dalam memasuki pendidikan lebih lanjut; Mengembangkan kepribadian dan potensi diri sesuai dengan tahap perkembangan peserta didik; (c) membantu meletakkan dasar ke arah perkembangan sikap, pengetahuan, keterampilan, dan daya cipta yang diperlukan oleh anak didik dalam menyesuaikan diri dengan lingkungannya dan untuk pertumbuhan serta perkembangan selanjutnya.

Sedangkan prinsip penyelenggaraan pendidikan TK berdasarkan Surat Edaran Depdiknas Nomor 1839/C.C2/TU/2009 adalah "Bermain sambil Belajar dan Belajar seraya Bermain". Bermain merupakan cara terbaik untuk mengembangkan potensi anak didik. Sebelum bersekolah, bermain merupakan cara alamiah untuk menemukan lingkungan, orang lain dan dirinya sendiri. Melalui pendekatan bermain, anak-anak dapat mengembangkan aspek psikis dan fisik yang meliputi moral dan nilai-nilai agama, sosial emosional, kognitif, bahasa, fisik/motorik, kemandirian dan seni. Pada prinsipnya bermain mengandung makna yang menyenangkan, mengasikkan, tanpa ada paksaan dari luar diri anak, dan lebih mementingkan proses mengeksplorasi potensi diri daripada hasil akhir.

Ada rambu-rambu yang harus diperhatikan dalam penyelenggaraan pendidikan Anak TK, yang disesuaikan dengan kondisi perkembangan dan pertumbuhannya, tidak boleh diberi pekerjaan rumah (PR). Dan disaat tamat pendidikan jenjang terakhir (kelompok B) tidak boleh diadakan kegiatan seremonial yang tak sesuai dengan prinsip pendidikan TK. Pada usia 4 s.d 6 tahun, kebutuhan anak untuk bermain dan bersosialisasi lebih penting dibandingkan dengan kemampuan skolastik. Oleh karena itu, pendidikan di TK tidak diperkenankan memberikan pekerjaan rumah (PR) kepada anak didik dalam bentuk apapun.

Dari tahun ke tahun jumlah lembaga TK semakin bertambah seiring dengan kebutuhan anak usia dini yang harus dilayani. Peningkatan kuantitas lembaga TK ini diharapkan juga diiringi dengan peningkatan mutu layanan. Dalam rangka meningkatkan mutu pengelolaan TK, pemerintah berupaya untuk memfasilitasi, membina dan mengarahkan masyarakat agar memahami apa, mengapa, dan bagaimana menyelenggarakan pendidikan anak usia dini yang benar, sebagaimana yang terdapat di Kota Blitar dimana jumlah 
TK semakin bertambah, namun layanan pendidikan TK sebagian besar masih di kelola oleh pihak swasta.

Jumlah keseluruhan dari sekolah TK di Kota Blitar adalah 81 TK yang tersebar di tiga Kecamatan di Kota Blitar. Dari keseluruhan dari TK tersebut status dari TK ada yang masih pengelolaan Swasta ada pula yang telah menjadi Negeri.

Persebaran jumlah TK per Kecamatan yangmana di Kecamatan Sukorejo terdapat 25 TK, Kecamatan Kepanjenkidul 24 TK dan Kecamatan Sananwetan 32 TK. Dari total jumlah TK yang berada di Kota Blitar Tersebut, status pengelolaan TK ada yang berstatus negeri dan adapula yang berstatus swasta. Berdasarkan data yang bersumber dari portal Kementerian Pendidikan dan Kebudayaan, di Kecamatan Kepanjenkidul dari total 24 TK, 4 TK telah berstatus negeri dan 20 TK berstatus swasta. Kecamatan Sananwetan dari total 32 TK yang ada, 4 TK telah berstatus negeri dan 28 TK berstatus swasta. Kecamatan Sukorejo dari total 25 TK yang ada, 4 TK telah berstatus negeri dan 21 TK berstatus swasta.

Jumlah penduduk pada usia TK secara keseluruhan harus dapat dihitung secara terperinci, begitu pula jumlah penduduk usia TK yang bisa masuk TK juga harus terhitung secara jelas. Langkah tersebut dilakukan guna mengatasi jumlah anak usia TK yang belum masuk TK. Dimana permasalahan pokok dari anak usia TK yang belum masuk TK muncul dengan alasan mahalnya biaya pendidikan Taman KanakKanak.

Berpijak dari permasalahan tersebut, harapannya seluruh Taman Kanak-Kanak yang ada di Kota Blitar mampu mengembangkan dan meningkatkan kualitas sekolahnya demi upaya untuk meningkatkan angka partisipasi anak-anak untuk menempuh pendidikan sejak dini, meskipun saat ini APK PAUD di Kota Blitar sudah mencapai 94,8 \%. Hal tersebut selaras dengan Misi ke-2 dari Pemerintah Kota Blitar, yaitu "Meningkatkan Kualitas SDM yang cerdas dan Berdaya Saing Tinggi".

\section{KAJIAN LITERATUR}

Strategi adalah sejumlah keputusan dan aksi yang ditujukan untuk mencapai tujuan (goal) dalam menyesuaikan sumber daya organisasi dengan peluang dan tantangan yang dihadapi dalam linggkungan industrinya (Kuncoro, 2006)

Sedangkan menurut siagian P. sondang Strategi adalah serangkaian keputusan dan tindakan sadar yang dibuat oleh managemen puncak dandi implementasikan oleh seluruh jajaran dalam suatu organisasi dalam rangka mencapai tujuan organisasi tersebut. (Siagian,2004)

Kata "strategi" dalam kamus besar bahasa Indonesia mempunyai beberapa arti, antara lain (a) ilmu dan seni mengembangkan semua sumber daya bangsa untuk melaksanakan kebijaksanaan tertentu dalam perang dan damai. (b) Ilmu dan seni memimpin bala tentara untuk menghadapi musuh dalam kondisi perang atau dalam kondisi yang menguntungkan. (c) Rencana yang cermat mengenai kegiatan untuk mencapai sasaran khusus (Afif,2003)

Selain itu pengertian strategi menurut para ahli yang lainnya seperti Carl Von Clausewitz (1989) menyebutkan bahwa stategi merupakan pengetahuan tentang penggunaan pertempuran untuk memenangkan sebuah peperangan. Perang itu sendiri merupakan kelanjutan dari politik. A.Halim (2012) menerangkan bahwa strategi merupakan suatu cara dimana sebuah lembaga atau organisasi akan mencapai tujuannya sesuai peluang dan ancaman lingkungan eksternal yang dihadapi serta kemampuan internal dan sumber daya. Morrisey (1995) mengatakan bahwa strategi ialah proses untuk 
menentukan arah yang harus dituju oleh perusahaan supaya dapat tercapai segala misinya.

Lebih lanjut Pearce dan Robinson (2014), menguraikan bahwa strategi menurut mereka adalah rencana main dari suatu perusahaan, yang mencerminkan kesadaran suatu perusahaan mengenai kapan, dimana dan bagaimana ia harus bersaing dalam menghadapi lawan dengan maksud dan tujuan tertentu. Rangkuti (2013) mengatakan bahwa strategi adalah alat untuk mencapai tujuan. Selanjutnya ada Craig dan Grant (1996), dimana menurut mereka strategi yaitu penetapan tujuan dan sasaran dalam jangka. Kemudian Johnson dan Scholes (2016), menyebutkan bahwa yang dimaksud strategi ialah arah dan ruang lingkup dari sebuah organisasi atau lembaga dalam jangka panjang yang mencapai keuntungan melalui konfigurasi dari sumber daya dalam lingkungan yang menantang, demi memenuhi kebutuhan pasar dan suatu kepentingan.

Selanjutnya ada Siagaan (2004), yang menjelaskan strategi merupakan serangkaian keputusan dan tindakan yang mendasar yang dibuat oleh menejemen puncak dan diterapkan seluruh jajaran dalam suatu organisasi demi pencapaian tujuan organisasi tersebut. Kaplan dan Norton (2000), menyebutkan bahwa strategi merupakan seperangkat hipotesis dalam model hubungan cause dan effect yakni suatu hubungan yang bisa diekspresikan dengan hubungan antara if dan then. Kemudian Syafrizal (2010), menerangkan bahwa strategi ialah cara untuk mencapai sebuah tujuan berdasarkan analisa terhadap faktor eksternal dan internal. Berdasarkan pendapat berbagai pakar tersebut, diksi strategi memiliki muatan yang sangat penting dalam tercapainya suatu tujuan.

\section{METODE PENELITIAN}

Penelitian ini menggunakan jenis penelitian kombinasi (Mix Methode) dengan metode survei. Jenis ini menggabungkan pendekatan kualitatif dan kuantitatif (Creswell: 2009). Lokasi penelitian adalah wilayah administratif Kota Blitar Provinsi Jawa Timur dengan waktu pengumpulan data pada periode bulan Maret- Juni 2019.

Dalam pelaksanaan survei, data lapangan dihimpun menggunakan kuesioner, wawancara, dokumentasi dan FGD. Kuesioner yang disusun adalah merujuk kepada Peraturan Menteri Pendidikan dan Kebudayaan No. 137 Tahun 2014 tentang standar Nasional Pendidikan Anak Usia Dini. Pemilihan aturan tersebut sebagai upaya untuk mengidentifikasi kondisi terkini lembaga Pendidikan TK di Kota Blitar. Karena aturan tersebut hadir sebagai dasar dalam perencanaan, pelaksanaan, pengawasan, dan tindak lanjut pendidikan dalam rangka mewujudkan lembaga TK bermutu, sebagai acuan untuk mewujudkan tujuan pendidikan nasional serta dasar penjaminan mutu pendidikan TK di lingkungan Kota Blitar. Aturan tersebut akan melihat pencapaian lembaga pendidikan TK di Kota Blitar berdasarkan 3 aspek yang meliputi aspek pengelolaan dan penyelenggaraan TK; aspek kualitas pendidik dan tenaga pendidik; dan aspek ketersediaan perlengkapan dasar, sarana dan prasarana.

Dengan menggunakan instrumen kajian yang merujuk kepada aturan tersebut akan membantu peneliti untuk menganalisis gambaran terkini kondisi lembaga pendidikan TK di Kota Blitar.

Kelompok sasaran yang hendak dijadikan lokasi penelitian meliputi sejumlah TK dilingkup Kecamatan Kepanjenkidul, Kecamatan Sananwetan dan Kecamatan Sukorejo. Beberapa kriteria yang ditentukan adalah meliputi TK di Kota 
Blitar yang berstatus swasta; TK swasta di Kota Blitar yang telah bersedia untuk diubah pengelolaannya dari pengelolaan oleh yayasan menjadi pengelolaan oleh Pemerintah Daerah Kota Blitar; TK swasta di Kota Blitar yang memiliki ijin dan legalitas yang sah menurut peraturan perundangundangan; TK swasta yang minimal telah memenuhi standar Peraturan Menteri No. 137 Tahun 2014 tentang Standar Nasional Pendidikan Anak Usia Dini.

\section{HASIL DAN PEMBAHASAN}

Strategi pengembangan lembaga TK di Kota Blitar dapat dihasilkan berdasarkan analisis terhadap faktor-faktor internal yang mempengaruhi dalam penyelenggaraan pembelajaran di TK yang ada di Kota Blitar masing-masing. Penyelenggaraan tersebut secara tidak langsung akan mencerminkan sisi keunggulan dan kelemahan dari TK yang ada di Kota Blitar. Selain keunggulan dan kelemahan yang nantinya akan ditemukan, strategi pengembangan TK juga membutuhkan temuan data yang terkait dengan faktor eksternal yang mempengaruhi dalam penyelenggaraan pembelajaran di TK. Faktor eksternal tersebut menghasilkan tantangan dan peluang dari TK masing-masing sebagaimana tabel 1 berikut.

Tabel 1. Klasifikasi Faktor Internal dan Eksternal Pengembangan Lembaga TK

Keunggulan

- TK di Kota Blitar telah mengacu STPPA (Standar tingkat Pencapaian Perkembangan Anak) yang menjadi dasar dalam penyelenggaraan standar TK lainnya.
Peluang

- Tersedianya BOP (Bantuan Operasional Pendidikan Anak Usia Dini) yang dapat diakses oleh TK di Kota Blitar
Kelemahan

- Belum Optimalnya Sarana dan Prasarana Pendukung (SPM dalam hal penyediaan 6 buah buku gambar per peserta didik per semester $77 \%$, TK belum menyediakan ruang tempat UKS dengan kelengkapan P3K (Pertolongan Pertama Pada Kecelakaan)61\%)

- Kurangnya Pengetahuan tentang pengadministrasian pencairan dana dari pemerintah

Berdasarkan hal itu, faktor internal dan eksternal yang dimiliki oleh TK yang ada di Kota Blitar kemudian akan diolah untuk menghasilkan strategi pengembangan. Strategi pengembangan tersebut sebagai upaya untuk meminimalisir kelemahan dan tantangan yang ada dan dialami oleh TK yang berada di Kota Blitar.

Berdasarkan faktor keunggulan internal bahwa sebagian besar TK telah memiliki keunggulan yang telah tercermin dari penyelenggaraan pembelajaran di TK mereka masing-masing. secara garis besar, TK yang ada di Kota Blitar dalam aspek

\section{Tantangan}

- Persaingan antara TK satu dengan yang lain dalam hal penerimaan peserta didik baru yang semakin ketat.

- Dana BOP yang semakin lama dirasa semakin sulit administrasi pencairannya
STPPA (Standar Tingkat Pencapaian Perkembangan Anak) telah terselenggara. Sebenarnya STPPA merupakan acuan yang akan menentukan keberlanjutan dari standar penyelenggaraan TK diantaranya standar isi, proses, penilaian, standar pendidik dan tenaga kependidikan, sarana dan prasarana, pengelolaan serta pembiayaan. STPPA ini menjadi keunggulan yang dimiliki oleh sebagian besar TK di Kota Blitar. Karena sebagian besar dari mereka telah mengacu STPPA dalam penyelenggaraan TK di standar isi dan proses yang tertuang dalam Program 
pengembangan yang disajikan dalam bentuk tema dan subtema, RPPM, RPPH. Begitu halnya dengan standar pendidik, bahwa sebagian besar guru TK telah memiliki sertifikat profesi guru TK sebagai pengejawantahan standar pendidik menurut permendikbud no 137 tentang Standar Nasional TK.

Berdasarkan faktor kelemahan internal bahwa Sebagian besar dari TK yang ada di Kota Blitar belum maksimal dalam pencapaian SPM TK berdasarkan Permendikbud No 32 Tahun 2018 tentang Standar Pelayanan Minimal Pendidikan. SPM yang masih belum maksimal tersebut adalah penyediaan 6 buah buku gambar per peserta didik per semester. Sebagian besar TK yang ada masih belum menyediaakan sesuai dengan batas minimal yang telah ditentukan oleh pemerintah. Selain itu, kelemahan lain yang dialami adalah sebagian besar TK belum maksimal dalam penyediaan sarana dan prasarana pendukung pembelajaran TK. Hal tersebut disebabkan karena sebagian besar dana yang digunakan oleh mereka (TK) adalah dana BOP pemerintah. Sayangnya dana tersebut memang dilarang digunakan untuk pembangunan dan rehab sarana serta prasarana yang dimiliki. Padahal adanya sarana dan prasarana dari TK menjadi modal mereka untuk bisa mendapatkan peserta didik karena itu sebagian dari pada branding dari sekolah mereka. Kelemahan lain yang dimiliki adalah dalam hal pengelolaan dana BOP. Dana ini adalah dana dari pemerintah yang bisa diakses oleh TK Negeri maupun Swasta dengan beberapa ketentuan yang berlaku. Sebagian besar daripada TK yang ada masih kebingungan dalam proses pencairan dana BOP tersebut.

Berdasarkan faktor tantangan, tantangan yang dihadapi oleh TK di Kota Blitar. Tantangan-tantangan tersebut meliputi Jarak TK satu dengan yang lain berdekatan, Sekolah Negeri yang Gratis berimbas kepada TK Swasta, Bermunculan Sekolah TK Baru, Letak Sekolah kurang strategis / masuk kedalam gang, Dana dari Pemerintah tidak bisa dibuat untuk renovasi, Keinginan Walisiswa yang tinggi, Banyak Bermunculan TK Baru dengan Fasilitas yang menarik, Banyak wali siswa yang menyekolahkan anaknya di pusat kota, Wali siswa yang mampu memilih ke sekolah favorit, Bantuan BOP semakin rumit Pencairannya.

Secara garis besar banyak ditemukan tantangan yang dialami oleh TK di Kota Blitar yang meliputi Jarak TK satu dengan yang lain berdekatan, Sekolah Negeri yang Gratis berimbas kepada TK Swasta, Bermunculan Sekolah TK Baru, Letak Sekolah kurang strategis / masuk kedalam gang, Dana dari Pemerintah tidak bisa dibuat untuk renovasi, Keinginan Walisiswa yang tinggi, Banyak Bermunculan TK Baru dengan Fasilitas yang menarik, Banyak wali siswa yang menyekolahkan anaknya di pusat kota, Wali siswa yang mampu memilih ke sekolah favorit merujuk kepada kegalauan TK dalam menghadapi Persaingan dalam penerimaan peserta didik baru.

Disisi lain tantangan BOP yang semakin rumit tersebut sebagai tantangan yang bermuara kepada kelemahan dari TK dalam memahami aturan dalam pengelolaan dana BOP tersebut guna meningkatkan daya tarik TK untuk bersaing mendapatkan peserta didik baru.

Berdasarkan faktor peluang, peluang yang dimiliki oleh TK di Kota Blitar secara garis besar meliputi Adanya BOP Anak dari keluarga tidak mampu lebih memilih TK Negeri, Afiliasi lembaga yang dimiliki, Lokasi Sekolah dekat Tempat Wisata.

Beberapa TK di Kota Blitar mengakui bahwa BOP merupakan peluang yang bisa 
dimanfaatkan. Walaupun disisi lain adanya BOP juga menjadi tantangan. TK yang berstatus Negeri memiliki peluang yang berbeda dengan TK yang berstatus swasta. TK Negeri memiliki peluang dukungan dana dari pemerintah yang membuat biaya TK mereka menjadi gratis. Akibatnya, anak dari keluarga tidak mampu lebih memilih untuk bersekolah di TK Negeri. Disisi lain hal tersebut menjadi tantangan untuk TK swasta.

TK berstatus Swasta yang merupakan afiliasi dari lembaga/institusi tertentu memiliki peluang lain dari sisi keanggotaan lembaga yang lebih memilih untuk mensekolahkan anaknya ke TK yang berafiliasi dengan lembaga tempat orangtua peserta didik bekerja.

TK tertentu juga memiliki peluang dalam hal lokasi sekolah dekat dengan tempat wisata. Hal tersebut memberikan keuntungan tersendiri karena akan menjadi daya tarik tersendiri terhadap para calon orangtua peserta didik.

Secara garis besar peluang yang dimiliki TK yang ada di Kota Blitar tidak secara bersama dirasakan oleh keseluruhan TK. Hanya saja ketika digeneralisasi bahwa peluang yang dimiliki oleh TK yang ada di Kota Blitar adalah adanya BOP yang dapat diakses untuk mendukung pembiayaan penyelenggaraan TK sesuai dengan peruntukannya.

\section{Strategi Pengembangan}

Strategi merupakan konversi dari persoalan yang telah ditemukan di lapangan menyesuikan kondisi eksisting dalam upayanya untuk melakukan pengembangan ke arah yang lebih optimal dibanding dengan kondisi eksisting yang ada. Strategi pengembangan lembaga pendidikan TK disusun berdasarkan analisis faktor internal dan eksternal sebagaimana tabel berikut.

Tabel 2. Analisis SWOT berdasarkan pengungkit utama disetiap faktor internal dan ekstenal

Keunggulan (S)

- TK di Kota Blitar telah mengacu

STPPA ( Standar tingkat

Pencapaian Perkembangan

Anak) yang menjadi dasar

dalam penyelenggaraan

standar TK lainnya.
Strategi SO

Peluang (0)

- Optimalisasi Penggunaan dana BOP dalam mendukung pencapaian STPPA
Tersedianya BOP yang dapat diakses oleh TK di Kota Blitar

\begin{tabular}{|c|c|c|}
\hline Kelemahan (W) & Tantangan (T) & Strategi WT \\
\hline $\begin{array}{l}\text { Belum Optimalnya Sarana dan } \\
\text { Prasarana Pendukung (SPM } \\
\text { dalam hal penyediaan } 6 \text { buah } \\
\text { buku gambar per peserta didik } \\
\text { per semester, TK belum } \\
\text { menyediakan ruang tempat } \\
\text { UKS dengan kelengkapan P3K } \\
\text { (Pertolongan Pertama Pada } \\
\text { Kecelakaan) } \\
\text { - Kurangnya Pengetahuan } \\
\text { tentang pengadministrasian } \\
\text { pencairan dana dari pemerintah }\end{array}$ & $\begin{array}{l}\text { - Persaingan antara TK satu } \\
\text { dengan yang lain dalam hal } \\
\text { penerimaan peserta didik baru } \\
\text { yang semakin ketat. } \\
\text { - Dana BOP yang semakin lama } \\
\text { dirasa semakin sulit administrasi } \\
\text { pencairannya }\end{array}$ & $\begin{array}{ll}\text { - } & \text { Optimalisasi Pengelolaan TK } \\
\text { melalui Sumber Pendapatan } \\
\text { Baru selain SPP dan BOP } \\
\text { - } \\
\text { Pengawasan Penggunaan dana } \\
\text { BOP }\end{array}$ \\
\hline
\end{tabular}

\begin{tabular}{ll}
\hline Strategi SW & Strategi OT \\
\hline Memanfaatkan segala sarana & - Optimalisasi Penggunaan BOP \\
prasarana serta tenaga dan & dalam meningkatkan daya saing \\
pikiran dalam mendukung & TK \\
STPPA &
\end{tabular}


Berdasarkan analisis tersebut, terdapat tiga strategi yang dapat dihasilkan untuk mengatasi persoalan pengembangan lembaga TK di Kota Blitar yang meliputi

(1)Pendampingan dalam penganggaran dan pengawasan penggunaan dana BOP. Strategi ini merupakan gabungan dari strategi SO, OT dan WT 1. Pendampingan dalam penganggaran dan pengelolaan BOP perlu untuk dilakukan sebagai upaya yang dilatar belakangi oleh persoalan internal dari beberapa TK yang menyebutkan bahwa mereka merasa kesulitan dalam hal pencairan dana dari Pemerintah, banyak dari TK yang belum mampu mencapai SPM penyediaan 6 buah buku gambar per peserta didik per semester. Persoalan internal lain yang dimiliki adalah dalam hal pengelolaan dana BOP. Dana ini adalah dana dari pemerintah yang bisa diakses oleh TK negeri maupun swasta dengan persyaratan yang telah diatur oleh Pemerintah. Sebagian besar dari lembaga TK yang ada masih kesulitan dalam proses pengajuan dan pencairan dana BOP tersebut. Padahal penggunaan dana BOP sesuai aturan dalam komponen kegiatan pembelajaran dan bermain bisa dipergunakan untuk pengadaan bahan bermain dan bahan belajar TK yang dibutuhkan sesuai dengan kegiatan tematik, dalam hal ini pelaksanaan SPM penyediaan buku gambar dapat ditopang menggunakan dana dari BOP karena aturan memperbolehkan hal tersebut. Selain itu, penggunaan dana BOP sesuai aturan dalam komponen kegiatan pendukung dapat dipergunakan untuk pengadaan alat-alat deteksi dini tumbuh kembang (DDTK, pembelian obat-obatan ringan, dan isi kotak pertolongan pertama kecelakaan (P3K). Maka dari itu, penting kiranya persoalan yang dihadapi oleh TK dengan latar belakang belum optimalnya pemahaman mereka terkait penggunaan dana BOP perlu untuk ditindak lanjuti dengan adanya strategi pendampingan yang intensif terhadap lembaga TK.
(2)Peningkatan hubungan kerjasama Lembaga TK melalui skema sponsorship. Strategi ini merupakan konversi dari strategi WT 2. Strategi ini bertujuan untuk mengoptimalisasi sumber pendapatan TK diluar BOP dan SPP. Secara garis besar banyak ditemukan tantangan yang dialami oleh TK di Kota Blitar yang meliputi Jarak TK satu dengan yang lain berdekatan, sekolah negeri yang gratis berimbas kepada TK swasta, bermunculan sekolah TK baru, letak sekolah kurang strategis/masuk kedalam gang, dana dari pemerintah tidak bisa dibuat untuk renovasi, keinginan wali siswa yang tinggi, banyak bermunculan tk baru dengan fasilitas yang menarik, Banyak wali siswa yang menyekolahkan anaknya di pusat kota, wali siswa dengan kelebihan ekonomi lebih memilih sekolah favorit. Semua hal tersebut merujuk kepada kegalauan lembaga TK dalam menghadapi persaingan dalam penerimaan peserta didik baru. Berdasarkan hal itu permasalahan pokok yang dihadapi oleh TK di Kota Blitar adalah belum optimalnya kualitas lembaga TK yang mereka naungi. Kondisi tersebut yang melatarbelakangi rendahnya sisi branding lembaga TK terhadap permintaan orangtua peserta didik yang akan lebih memilih mensekolahkan anak mereka di lembaga dengan bentuk dan tampilan fisik sarana dan prasarana yang lebih tampak dan terkesan berkualitas. Maka dari itu, selain lembaga TK perlu untuk memanfaatkan BOP sebaik mungkin untuk melakukan branding, penting bagi mereka untuk meningkatkan inovasi dan kreativitas dalam upaya untuk meningkatkan kualitas lembaga TK mereka masing-masing. Hal tersebut akan mampu dilakukan jika lembaga TK menemukan formulasi tepat untuk mencari sumber pendapatan tambahan selain SPP dan BOP. Hal tersebut bisa meliputi pengajuan sponsorship dengan sektor swasta yang berkaitan.

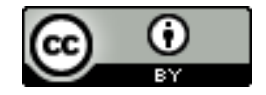


(3)Standarisasi sarana dan prasarana minimal sebagai upaya menekan ketimpangan ketersediaan sarana dan prasarana pada lembaga TK di Kota Blitar. Strategi ini merupakan konversi dari strategi SW. Persoalan yang di hadapi TK di Kota Blitar dalam upaya untuk melakukan perkembangan adalah belum optimalnya sarana dan prasarana pendukung. Sarana dan prasarana pendukung yang dimaksud meliputi belum optimalnya pelaksanaan SPM (Standar Pelayanan Minimal) penyediaan 6 buah buku gambar per peserta didik per-semester. Kemudian belum tersedianya ruang tempat UKS dengan kelengkapan P3K (pertolongan pertama pada kecelakaan). Berdasarkan hal tersebut diatas memang penting kiranya dilakukan pentahapan pengembangan oleh Dinas Pendidikan Kota Blitar dalam melakukan pengembangan TK yang merujuk kepada persoalan sarana dan prasarana TK di Kota Blitar. Pentahapan pengembangan tersebut dilakukan dengan melakukan standarisasi sarana dan prasarana minimal dengan menyesuaikan kondisi eksisting pada sebagian besar lembaga TK di Kota Blitar.

\section{PENUTUP}

terdapat tiga strategi yang dapat dihasilkan untuk mengatasi persoalan pengembangan lembaga TK di Kota Blitar yang meliputi (1)Pendampingan dalam penganggaran dan pengawasan penggunaan dana BOP. Karena penting kiranya persoalan yang dihadapi oleh TK dengan latar belakang belum optimalnya pemahaman mereka terkait penggunaan dana BOP perlu untuk ditindak lanjuti dengan adanya strategi pendampingan yang intensif terhadap lembaga TK.

(2)Peningkatan hubungan kerjasama Lembaga TK melalui skema sponsorship. Karena selain lembaga TK perlu untuk memanfaatkan BOP sebaik mungkin untuk melakukan branding, penting bagi mereka untuk meningkatkan inovasi dan kreativitas dalam upaya untuk meningkatkan kualitas lembaga TK mereka masing-masing melalui pembangunan hubungan kerjasama dengan pihak luar.

(3)Standarisasi sarana dan prasarana minimal sebagai upaya menekan ketimpangan ketersediaan sarana dan prasarana pada lembaga TK di Kota Blitar. Karena penting kiranya dilakukan pentahapan pengembangan oleh Dinas Pendidikan Kota Blitar dalam melakukan pengembangan TK yang merujuk kepada persoalan sarana dan prasarana TK di Kota Blitar.

\section{DAFTAR PUSTAKA}

A.Pearce, John II, Richard B.Robinson, Jr. (2014). Manajemen strategi. Jakarta: Salemba Empat.

Abdul, Halim. (2012). Pengaruh Strategi Pembelajaran dan Gaya Belajar terhadap Hasil Belajar Fisika siswa SMPN 2 Secanggang Kabupaten Langkat, Jurnal Tabularasa PPS UNIMED. Vol.9 No.2, Desember 2012.

Carl Von Clausewitz, (1989). On War Princeton University Press New Jersey

Craig \& Grant. (1996). Manajemen Strategi. Jakarta: Alex Media Komputindo Kelompok Gramedia

Creswell, John W. (2009). Research Design Pendekatan Penelitian Kualitatif, Kuantitatif, dan Mixed. Yogyakarta: Pustaka Pelajar. Penterjemah Achmad Fawaid.

Faisal Afif, (1984). Strategi Menurut Para Ahli, (Bandung : Angkasa)

Johnson, G. and Scholes, K. (2016). Exploring Corporate Strategy-Text and Cases. Hemel Hempstead: Prentice-Hall.

Kaplan, Robert S., dan Norton, David P., (2000) Balanced Scorecard : 
Menerapkan Strategi Menjadi Aksi, Erlangga, Jakarta,

Masitoh, dkk. (2005). Strategi Pembelajaran TK. Jakarta: Pusat Penerbitan Universitas Terbuka

Moeslichatoen R. (2004). Metode Pengajaran Di Taman Kanak - Kanak. Jakarta: PT Asdi Mahasatya

Morrisey, George.,L. (1995). A Guide to Strategic Thinking: Building Your Planning Foundation. San Francisco: Jossey-Bass

Mudrajad Kuncoro, (2006) Strategi Bagaimana Meraih Keunggulan

Kompetitif, (Jakarta: erlangga,)

Peraturan Menteri Pendidikan dan Kebudayaan No 137 tentang Standar Nasional TK.
Peraturan Menteri Pendidikan dan Kebudayaan No 32 Tahun 2018 tentang Standar Pelayanan Minimal Pendidikan

Rangkuti, Freddy. (2013). Analisis SWOT Teknik Membedah Kasus Bisnis. Jakarta: Gramedia Pustaka Utama

Siagian P. Sondang, (2004) Managemen Strategi, (bumi aksara, Jakarta,

Situmorang, Syafizal Helmi. (2010). Analisis Data. Medan:USU Press.

Surat Edaran Depdiknas Nomor 1839/C.C2/TU/2009 tentang Penyelenggaraan Pendidikan Taman Kanak-Kanak dan Penerimaan Siswa Baru Sekolah Dasar

Undang Republik Indonesia Nomor 20 Tahun 2003 tentang Sisdiknas 